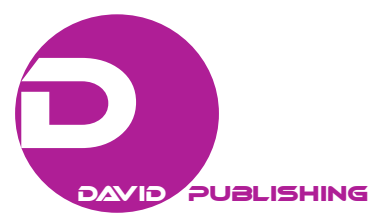

\title{
Research on Franchising Model in Small Business
}

\author{
Mengyao Tang \\ Jianghan University, Wuhan, China
}

\begin{abstract}
Franchising business has been identified as a successful business option that often sustains the business owner over the challenging of the business world. It also has been recognized as an optimal way to choose for when one has just begun to start a business with lack of experiences. This report provides more in depth discussion to this mater, trying to find out the key factors that lead to the success of franchise enterprises, meanwhile summarising the main advantages and limitations in the model, then analysing the potential weaknesses, at last, providing the conclusion for choosing the franchising model when starting a small business.
\end{abstract}

Keywords: franchising, success factors, advantages and disadvantages, weakness

\section{Introduction}

The past decades have witnessed multitude new challenges to small, medium, and large firms. The Asian financial market crash, global economic fluctuation, and significantly competitive internal and external market environments have directly or indirectly impacted on the success and failure of numerous small businesses (Slattery, 2002). In this context, franchising is often recognised as an effective business arrangement that generally survives such economic turbulence and also generates a high business success rate (Stanworth \& Curran, 1999; Storholm \& Scheuing, 1994). Apparently, "franchising is already well known and has an increasing role in national economies” (Hamid, Othman, Hassan, Selamat, \& Mastor, 2003, p. 4). It also emphasizes that franchising is an excellent business format, which would be the most successful way of market expansion in 2010. However, the franchising industry continues to work through a challenging economic and political climate (Walker, 2010). Prospective franchisees should carefully weigh all the "pros and cons". This literature review will give a broad view of the definition of a franchise as well as address some factors contributing to the success of global top franchises. It will also emphasize major advantages and disadvantages of a franchise.

\section{Key Success Factors of Top Global Franchises}

\section{Strong Internationally Recognized Brands}

Strong and internationally recognized brands may be an essential factor for the franchise success. Consumers generally hold franchise products or services with a reliable brand name and trademark in high regard (Falbe Dianne \& Cecilia, 1998). For example, according to the top 100 Global Franchise Report (2009), with 32,000 units in over 60\% of the world's countries, McDonald's Golden Arches and its mascot Ronald McDonald have gained universal recognition. Likewise, with 15,000 units, KFC's Colonel Sander's Mascot is

Mengyao Tang, lecturer, Institute of Accounting of Jianghan University, Wuhan, China.

Correspondence concerning this article should be addressed to Mengyao Tang, Jianghan University, Wuhan Economic \& Technological Development Zone, Wuhan, China. 
recognized around the world. Undoubtedly, effective brand management helps the top franchise operations maintain the integrity and consistency of their brands. Wherever the franchise is located worldwide the same quality of product and service is delivered and the same message is communicated.

Table 1

Top 10 Global Franchises

\begin{tabular}{llll}
\hline Ranking & Franchise name & Industry & Country \\
\hline 1 & McDonald's & Food & USA \\
2 & KFC & Food & USA \\
3 & Burger King & Food & USA \\
4 & Subway & Food & USA \\
5 & 7-Eleven & Convenience Store & USA \\
6 & Hertz & Car Rental \& Dealer & USA \\
7 & Pizza Hut & Food & USA \\
8 & Marriott International & Hotel & USA \\
9 & Wyndham Hotels and Resorts & Hotel & USA \\
10 & Hilton Hotels \& Resorts & Hotel & USA \\
\hline
\end{tabular}

Source: http://www.franchisedirect.com/top100globalfranchises/rankings/.

\section{Comprehensive Training and Ongoing Support}

The top 100 Global Franchise Report (2009) states that the leading franchise companies recognise the importance of intensive training follow-up support and continuous learning. According to Williams (1999), Falbe and Cecilia (1998), the provision of franchisor training and support enables transfer of business related to knowledge from franchisor to franchisee. Darr, Argote and Epple (1995) emphasize that the knowledge transfers between franchise firms build an increased likelihood of franchise business success. Strong technical and business training ensures that customers receive excellent service and quality of products, which also ensure the success of each franchise unit.

According to the top 100 global franchise report (2009), for instance, subway provides food service training, business guidance, and follow-up support from an extensive network of regional and headquarters personnel. Quality training and skill development linked to constant support systems for franchisees are what differentiates the Top 100 Franchises (Mesurier, 2008).

\section{Adaptability and Innovation}

The most successful franchises are innovative and adaptable to a changing marketplace (The top 100 Global Franchise Report, 2009). The leading quick service restaurant chains for example, constantly offer new choices including healthier options, new toppings, new breads, fillings etc. In 2003, Pizza Hut introduced Wing Street Restaurants due to the rising popularity of chicken wings. Five years later they introduced restaurant quality pastas as people became more health conscious.

Expansion into international markets can be successful if the target market is researched and a plausible strategy is implemented. A franchise needs to be able to adapt to and change the cultural differences in a new market and to be aware of current trends. According to the top 100 Global Franchise Report (2009), for instance, in Saudi Arabia, no pork products are served as it is prohibited by Islamic law. All meat sold is "halal” so McDonald's serves the McArabia which contains no pork products. In Indiana, there are strict religious laws about food preparation. McDonald's has implemented a system where meat and vegetarian meals 
are prepared in separate areas of the restaurant and chefs preparing vegetarian dishes wear distinctive green aprons to adhere to the local laws.

\section{Advantages of Franchises}

\section{Minimized Business Risks \& Lower Failure Rate}

One of the advantages to franchise a business is that it usually has lower failure rate compared to starting a new independent small business. This is because unlike starting a new business that needs to learn by mistakes, franchisees could straightly enjoy the benefit of established product and brand name developed by franchisor's ongoing marketing effort (Schaper \& Volery, 2007). The lower risks to franchise a business reflect in the parent company which has already resolved most, if not all, of the problem areas in its systems and procedures (DiNatale, 2008).

Taking McDonald's as an example, one of its key factors to the world wide success is that every franchisee is required to use McDonald's recipes, menu items, trademarks, logos, restaurant layout, and display signage with a standard quality provided and uniformity product produced. Because of the required standards, franchisees have been avoided of learning from trial and error which will increase the probability of business success.

\section{Time \& Energy Saving on Product and Marketing Development}

Second advantage to franchise the business is that it helps new business owner save a large amount of time and energy on exploring, developing, and operating a new system (Seid \& Thomas, 2006). One does not need to start from scratching. As the business is already there, no goodwill needs to be created and everything is already in place for running the business (Strauss, 2005). As the brand, the trademark, and the reputation of the products are already there, the franchisees could simply start their own business by giving a license to market its products carrying a brand that is already familiar with the consumers from their franchisors (Buy a franchise: Advantages and disadvantages of franchising).

Many popular franchises have instant brand-name recognition and have created a loyal following among consumers. For example: McDonald's, KFC, and Starbucks. They all have the same brand name and same quality products which enable the franchisee to get into a business that already has a ready market (Seid \& Thomas, 2006).

\section{Lower the Cost in Buying Supplies and Advertising}

Third advantage to franchise the business is that it can help the franchisee optimally minimize the cost. This can be achieved as the franchisor can always use the combined power of many franchisees to negotiate discounts for the supply of raw materials (Spinelli, Rosenberg, \& Birley, 2004). A lower cost of the raw materials and other things from suppliers is assessable because the size and quantities of ordering is very huge; the discount could usually be given (Seid \& Thomas, 2006). This gives the franchises a big advantage over their competitors because they are able to reduce expenditures on a continuous basis. This procurement set-up is definitely more advantageous to the franchisee as against procuring supplies independently (Seid \& Thomas, 2006).

Besides the cost saved in buying supplies, Keup (2007) also pointed out that for advertising, one may suit for all franchise with same brand name. Moreover, the franchisors usually offer the national and local advertising; therefore the franchisees do not need to pay a large amount of money for the advertising compared to individual advertising (Luhn \& Wolfe, 1994). 


\section{Easily Access to the Fund Rising}

Fourth advantage to franchise the business is that it is usually easier to the fund rising. Due to the low risk borne, financial institutions are often more willing to lend money to buy a franchise business rather than to start a new, unknown enterprise (Murphy, 2006).

According to Sherman (2004) the ready market and rapid market penetration lowers the risk of franchise business. The failure of business could be further reduced by the improvement in competition, the existence of a captive market for products and services, and the reduced administrative and overhead costs. Hence, the lower the risk is, the easier it is access to fund from banks as well as other financial institutions.

\section{Pre-opening Benefits-Business Support and Training Provided}

When someone is pre-opening the franchise, the franchisor will usually provide assistances at the starting stage of the business. One can contact the franchisor if he encounters problems such as setting the equipment, the lease, shop fitting, or furnishing the store. Franchisor also provides assistance in determining the appropriate stock inventory for the opening of a business. This kind of support and the other benefits under the franchise agreement are what set franchising apart from other businesses (Daszkowski, 2010).

Most franchisors will provide continuing training for franchisee's business such as product preparation, quality standard, business controls, and some methods of managing employees. One of the examples to illustrate this is "Franchise Head Quarters will train you in everything from the technology involved, to the accounting, to standing behind the counter and taking money” (Daszkowski, 2010).

\section{Limitations}

\section{Franchise Fees and Profit Sharing}

According to Norman and Thomas (2006), Ferguson (2009), fees and capital requirements vary among the different franchisors. Normally, franchisees pay the start-up costs for the right to use the company name. Other additional start-up costs might include site purchase and preparation, construction, signs, fixtures, equipments, management assistance and training. Furthermore, franchisors also require ongoing royalty fee.

"Most franchisors require that you pay a percentage of your monthly gross sales back to the parent company” (Small Business \& Home Business Resource, 2004).

This fee usually involves a percentage of gross sales with a required minimum (flat fee levied) on the franchise. For example, Krispy Kreme's franchise fee is $\$ 40,000$ and its royalty is $5.5 \%$ of each unit’s sales. Potential franchisees must get paid even they fail to earn a profit. Murphy (1998) quotes "franchisees will lose control over their own profits”.

\section{Market Saturation}

Also Norman and Thomas (2006) advise franchisees should realise the market saturation is a very real danger due to the fact that some franchisors offer franchisees territorial protection, many do not. They may set up new franchises in close proximity to existing ones. Strazewski (1998) reported that the franchises "expect to see greater growth and less market saturation in the business and personal services industries.” The biggest challenge to the growth potential of franchising is the lack of satisfactory locations. For example, two shops of 7/11 on the same street with only 100 meters distance. Their markets are oversaturated and their sales are suffering. 


\section{Less Freedom}

McDonnell Macphee \& Associator declared that "there is little freedom or scope to be creative (Disadvantages of the Franchise System, 2008-2009)" and the main disadvantage of buying a franchise is that you have to do it in their way. When franchisees purchase franchises and sign the contract, they agree to sell the franchisor's product or service by following its prescribed formula. For example, when McDonald's rolls out a new product, franchisees have to put it in their menus, signs and so on.

The franchise agreement usually includes restrictions on how to run the business and not allow franchisees to make any change (Small Business \& Home Business Resource, 2004).

Franchisees may become too dependent upon the franchisor (Disadvantages of the Franchise System, 2008). For those people who want to be their own bosses and dislike under control by others should not choose the franchise route to business ownership.

\section{Weaknesses}

\section{Control of Management}

On the basic of transaction cost theory, there are some rule problems occurred between headquarters and franchisees, mainly including decision-making, operational control, and the design of incentive mechanisms (Paik \& Choi, 2007; Yin \& Zajac, 2004). Lafontaine and Shaw (2005) indicated that especially, when the franchise has a well-known brand, franchise headquarters need more control in order to prevent the franchisees having the free-riding behavior, therefore, they will intend to direct the management and operation (Minkler \& Park, 1994). As a result, if there is a lack of credible commitment and communication between franchisors and franchisees, it may cause uncertainty of management and increase of transaction costs.

\section{Conflict Between Franchisors and Franchisees}

According to agency theory, the relationship between the principles and agents is similar with the relationship between franchisors and franchisees. It is believed that most important issues are information asymmetry and ethical risks. Problems have been arising when there is a goal conflict between them. The main factor is that they may have different risk preferences, because for different risk attitudes, the same thing would have different views on the decision-making (Carney \& Gedajlovic, 1991; Eisenhardt, 1989). Lafontaine (1992) said that franchise organizations may face three agency problems consisting of adverse selection, moral hazard, and hold-up. In brief, adverse selection and moral hazard mean hidden information and hidden action. The former refers to the occurrence before franchisors conclude the contract with franchisees due to information asymmetry; franchisors hide certain information, resulting in franchisee's not making the best interests of decisions. The latter happens after concluding the contract; franchisers' behavior is not to consider the benefits of franchisees (Combs, Michael, \& Castrogiovanni, 2004).

\section{Resource Allocation}

From the view of resource scarcity theory, Fulop and Forward (1997) pointed out that the common problem is relationship between franchisors and franchisees mostly caused by different strategies and operational considerations, and adequate capital resources. For example, franchisors may adjust their main marketing strategy due to the limited resource, but the new one may not match franchisees' prospection. The willingness to change will lead to deterioration of relationship between franchisors and franchisees (Paik \& Choi, 2007). 


\section{Conclusion}

After comparing the franchising business and the small business, it is apparent that the franchisee can successfully start and run his business at a relative low risk and failure rate compared to the small business owner. They can easily penetrate into market with strongly recognised brand. As a franchisee, he can easily acquire good quality of materials since the franchisor has the bargain power to negotiate the price for him. However, as a private business owner, he has to spare more efforts to establish the initial brand and improve the awareness of the products, which is difficult due to the less competitive power in advertising and marketing. Besides, the private owner has the limited power to negotiate cheap price, but he can provide good quality of product with more expensive materials. Moreover, the franchisee intensively invests in finance, borrows short or long term loans from the bank to run the business, which is different from the private business owner, who runs cash business.

According to the research, it can be concluded that a franchising business may not be preferred over private business to some extents. It shows that the franchisee may be restricted to such code of conducts when running his business, and being flexible in management of business is a key factor for survival. However, he cannot extricate himself from some control and certain standards highlighted by the franchisor. In contrast, the small business owner has the autonomy over his own business as he can outline the rules himself.

\section{References}

Buy a franchise: Advantages and disadvantages of franchising. Businesslink, viewed 18/08 2010, http://www.businesslink.gov.uk/bdotg/action/detail?itemId=1073791408\&type=RESOURCES

Carney, M., \& Gedajlovic, E. (1991). Vertical integration in franchise systems: Agency theory and resource explanations. Strategic Management Journal, 12(8), 607-629.

Combs, J. G., Michael, S. C., \& Castrogiovanni, G. J. (2004). Franchising: A review and avenues to greater theoretical diversity. Journal of Management, 30(6), 907-931.

Darr, E. D., Argote, L., \& Epple, D. (1995). The acquisition, transfer, and depreciation of knowledge in service organizations: Productivity in franchises. Management Science, 41(11), 1750-1762.

Daszkowski, D. (2010). Advantages of franchising. About.com Guide, http://franchises.about.com/od/franchisebasics/tp/advantages-franchising.htm

DiNatale, J. (2008). Australian \& New Zealand business franchise guide. Mt Eliza, Vic: CGB Publishing.

Disadvantages of the franchise System. (2008). Franchise Council of Australia, viewed 15/08 2010, http://www.franchise.org.au/scripts/cgiip.exe/WService=FCAWWW/ccms.r?PageId=10111.

Disadvantages of the Franchise System. (2008-2009). McDonnell, McPhee \& Associates, viewed 15/08 2010, http://www.franchiseconsulting.net.au/html/s02_article/article_view.asp?id=104\&nav_cat_id=133\&nav_top_id=61

Eisenhardt, K. M. (1989). Agency theory: An assessment and review. Academy of Management Review, 14(1), 57-74.

Falbe Dianne, H. B., \& Cecilia, M. (1998). NAFTA and franchising: A comparison of franchisor perceptions of characteristics associated with franchisee success and failure in Canada, Mexico, and the United States. Journal of Business Venturing, 13(2), 151-171.

Ferguson. (2009). Entrepreneurs: Career in focus (3rd ed.). New York: Facts On File Inc.

Fulop, C., \& Forward, J. (1997). Insights into franchising: A review of empirical theoretical perspectives. Service Industries Journal, 17(4), 603-625.

Hamid, A. B. A., Othman, M. H. M., Hassan, M., Selamat, R., \& Mastor, N. (2003). An encouraging factors for entrepreneur in franchising: A Malaysia experience. A paper for the Small Enterprise Association of Australia and New Zealand 16th Annual Conference, Ballarat, 28 September-1 October.

Keup, E. J. (2007). Franchise bible: How to buy a franchise or franchise your own business. Madison, WI, Canada: CWL Publishing Enterprises, Inc. 
Lafontaine, F. (1992). Agency theory and franchising: Some empirical results. RAND Journal of Economics, 23(2), $263-283$.

Lafontaine, F., \& Shaw, K. L. (2005). Targeting managerial control: Evidence from franchising. RAND Journal of Economics, 36(1), 131-150.

Luhn, R., \& Wolfe, R. L. (1994). Buying your first franchise. California: The Crisp Publications.

Mesurier, K. L. (2008). Planning the key to franchise success. franchising, viewed 18/08/2010, http://www.smh.com.au/small-business/franchising/planning-the-key-to-franchise-success-20090619-cq46.html

Minkler, A. P., \& Park, T. A. (1994). Asset specificity and vertical integration in franchising. Review of Industrial Organization, 9(4), 409-423.

Murphy, K. B. (2006). The franchise handbook: A complete guide to all aspects of buying, selling or investing in a franchise. United States: Atlantic Publishing Group, Inc.

Paik, Y., \& Choi, D. (2007). Control, autonomy and collaboration in the fast food industry: A comparative study between domestic and international franchising. International Small Business Journal, 25(5), 539-562.

Schaper, M., \& Volery, T. (2007). Entrepreneurship and small business (2nd Pacific Rim Edition). Australia: John Wiley \& Sons, Ltd.

Seid, M., \& Thomas, D. (2006). Franchising for dummies. United States of America: Wiley Publishing, Inc.

Sherman, A. J. (2004). Franchising \& licensing: Two powerful ways to grow your business in any economy. New York: American Management Association.

Slattery, L. (2002). Running your own business using the expertise of others. Irish Times, 53.

Small Business \& Home Business Resource. (2004). Business Wealth, viewed 15/08 2010, http://www.businesswealth.com.au

Spinelli, S., Rosenberg, R., \& Birley, S. (2004). Franchising: Pathway to wealth creation. United States of America: Prentice Hall PTR.

Stanworth, J., \& Curran, J. (1999). Colas, burgers, shakes and shirkers: Towards sociological mode of franchising in the market economy. Journal of Business Venturing, 14(4), 323-344.

Storholm, G., \& Scheuing, E. E. (1994). Ethical implications of business format franchising. Journal of Business Ethics, 13(3), $181-188$

Strauss, S. D. (2005). The small business bible: Everything you need to know to succeed in your small business. Hoboken, New Jersey, the United States of America: John Wiley \& Son, Inc.

Strazewski, L. (1998). 1997 stocks roll up, down; larger franchises hold steadyst. Franchise Times, 4(1), 3.

The Top $100 \quad$ Global Franchises Report. http://www.franchisedirect.com/top100globalfranchises/the2009report/158/767/

Walker, K. (2010). Transform prospects into franchisees. Franchising World, 42(7), 4.

Williams, D. L. (1999). Why do entrepreneurs become franchisees? An empirical analysis of organizational choice. Journal of Business Venturing, 14(1), 103-124.

Yin, X., \& Zajac, E. (2004). The strategy/governance structure fit relationship: Theory and evidence in franchising arrangements. Strategic Management Journal, 25(4), 365-383. 